Rev. Biol. Trop., 46(1): 145-155, 1998

\title{
Growth effort of Sceloporus scalaris (Sauria: Phrynosomatidae) at La Michilía Biosphere Reserve, Mexico
}

\author{
Alfredo Ortega-Rubio ${ }^{1 *}$, RobertBarbault ${ }^{2}$, GonzaloHalffter $^{1}$ Aradit Castellanos $^{3}$ and Federico Salinas ${ }^{3}$ \\ Instituto de Ecología, Apdo. Postal No. 63 Xalapa, Veracruz 91000 México. \\ Ecole Normale Superieure, 46 Rue D’Ulm, Paris Cedex 05, France. * Present address: \\ Centro de Investigaciones Biológicas del Noroeste, Apdo. Postal No. 128, La Paz, 23000, Baja California Sur, México.
}

\section{Received 13-XI-1996. Corrected 24-IX-1997. Accepted 09-X-1997}

\begin{abstract}
Using Mark-Recapture methods the growth effort of Sceloporus scalaris was studied at La Michilla Biosphere Reserve, Durango, Mexico. A total of 146 recaptures on 68 individuals were obtained over four years on a $50000 \mathrm{~m}^{2}$ transect. To calculate the growth rate of Sceloporus scalaris individuals, we analyzed the data from two sources. The first using the recapture records of the same individuals over different seasons and the second using the records of cohorts during different periods. The growth effort of $S$. scalaris drastically diminishes as the organism grows. The growth rate of males and females is about equal for individuals from both clutches. In adults, where it is possible to compare among seasons, we measure quicker growth during the spring. The growth pattern of S. scalaris at La Michilla follows the predictions proposed by the Bertalanffy model. Maximum growth rates are in the younger age classes and these rates decrease as size increases. The growing period of S. scalaris is correlated with the seasons at La Michilla Biosphere Reserve. Newborn S. scalaris appear when the availability of nourishment is still the most propitious for growth at faster rates. Such adaptations to the environment determine many key population attributes of this species in this zone. The sexual maturity age of S. scalaris is very early at La Michilla, only 4.5 to 6 months. Undoubtedly, the growth pattern of S. scalaris at La Michilla Biosphere Reserve can help explain the structure and dynamics of this population.
\end{abstract}

Key words: Durango; Growth Effort; La Michilía Biosphere Reserve; Lizards; Mexico; Sceloporus scalaris.

The bunch grass lizard, Sceloporus scalaris Wiegmann is an small (62 mm SVL), very common and abundant Mexican lizard which distribution includes 22 states of the Mexican Republic (Smith 1939). In spite oftheir abundance and wide distribution, there exists relatively few studies concerning the ecological aspects of this animal (Ballinger and Congdon 1981). Most of the previous studies are devoted to taxonomical (Smith and Poglayen 1958, Smith and Hall 1974, Thomas and Dixon 1976, Stebbins 1966, Anderson 1972, Van Devender and Lowe 1977), and reproductive aspects (Stebbins 1954, Anderson 1962, Greene 1970, Smith and Hall
1974, Newlin 1976). Thereare no previous works dealing with the growth patterns of this species.

The growth pattern is a key aspect in the life history of any species (Andrews 1982). Growth ratesdetermine, among otherimportant attributes, the length reached at sexual maturity and the maximum size (Andrews 1976, Barbault 1975, Kaufmann 1981, Van Devender 1978). Body size, in many reptiles, determines crucial reproductive characteristics such as reproductive effort and clutch size (Barbault 1974, 1981). Thus, the study of growth patterns can help us to understand the structure, dynamics, and 
demography of any lizard population (Barbault 1975, 1981, Van Devender 1978).

\section{MATERIALS AND METHODS}

Study area: The study site, La Michilİa Biosphere Reserve, is in the southeast of the State of Durango, México, between $104^{\circ} 20^{\prime}$ ' and 104 ${ }^{\circ} 07^{\circ} \mathrm{W}$ and $23^{\circ} 20^{\circ}$ and $23^{\circ} 30^{\circ} \mathrm{N}$. Field work was done in the buffer zone of the Reserve.

The climate of the zone is temperate subhumid with a mean annual temperature range between $17.4^{\circ} \mathrm{C}$ and $20.7^{\circ} \mathrm{C}$ and a mean annual precipitation of $567 \mathrm{~mm}$, concentrated in the summer. The vegetation of the zone is typically an oak-pine forest but highly diversified, including 207plantspecies thatcontain 18 different Quercus species and 10 different Pinus species (Martİnez and Saldivar 1978).

Methods: A transect of 50 x I 000 m marked with stakeseach $10 \mathrm{~m}$, was established and census were taken over 4 years during the following months: September and December 1979; March, May, and September 1980 and 1982 and all the months of 1981. Each one of these 20 stays comprised 15 days. During each day, the transect was traversed by 3 persons for 4 to 7 hours in the search for lizard individuals. For each lizard observed, we recorded the date, the hour, its sex, its location in relation to the nearest stake and then we captured the lizard by hand.

For each lizard captured, we recorded the following data: body temperature with a cloacal thermometer (Wescott); snout-vent length and tail length to the nearest $0.1 \mathrm{~mm}$ with a metal caliper (Scala 222); and body mass to the nearest $0.1 \mathrm{~g}$ with a Pesola (TM). Captured individuals were marked both by toe clipping and by paint code (Tinkle 1967).
To calculate the growth rate of Sceloporus scalarisindividuals, data from tw• sources were analyzed. The first uses the recapture records of the same individuals during different seasons and the second uses the records of cohorts followed during different periods.

The data of individual recapture records were pooled by age class and by season. Using the size differences between capture and recapture of a particular individual, the Instantaneous Growth Rate (IGR) was calculated using the Barbault (1973) formula:

$$
\operatorname{IGR}=\frac{\mathrm{L}_{2}-\mathrm{L}_{1}}{\mathrm{~T}_{2}-\mathrm{T}_{1}}
$$

Where:

$\mathrm{L}_{1}=$ Individual size at time $\mathrm{T}_{1}$; at initial capture. $\mathrm{L}_{2}=$ Individual size at time $\mathrm{T}_{2}$; at recapture.

Based on the IGR, the Growing Effort index (GE) was calculated using the Barbault (1973) formula:

$$
\mathrm{GE}=\frac{\mathrm{IGR}}{\mathrm{L}}
$$

Where $L$ is the average individual length during the time interval $T_{2}-T_{1}$ and it was calculated using the formula:

$$
L=\frac{1}{2}\left(L_{1}+L_{2}\right)
$$

The differencesin individual body data, among captures and recaptures, were adjusted to the differential equations of the curves and models most frequently used to describe animal growth. For this purpose, we calculated the size increase per day percentage, also called Relative Growth Rate(RGR), using the method of Kaufman (1981): 


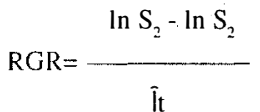

Where:

$S_{1}=$ Body size at the beginning of the time period.

$\mathrm{S}_{2}=$ Body size at the end of the period.

$\mathrm{t}=$ Time period.

RGR value is then plottedagainst the geometric means $(\mathrm{S}$ ) of the individual body size, $\mathrm{S}$, which is calculated in the following way:

$$
S=\left(S_{1} S_{2}\right)^{1 / 2}
$$

If the plotted data yield a straight line using semilog paper, a Gompertz curve can be used to describe the observed data pattern (Kaufman 1981). If a straight line is obtained using logarithmic paper, then a potency curve must be used and, if a straight line is obtained with linear graph paper, then the logistic or the Bertalanffy curves be can be used (Bertalanffy 1957, 1960, Kaufman 1981). It is possible to calculate the linear regression for the plotted data, and calculating the origin and the slope, to establish the differential equation that defines the pattern observed.

\section{RESULTS}

A total of 146 recaptures on 68 individuals were made during the 4 years of study. Individual averages were grouped by seasons on Table 1 . At La MichilIa, summer was humid and hot and winter was cold and dry (Martinez and Saldivar 1978). The age classes considered were (Ortega 1986): juveniles, individuals $<3$ months for both clutches; subadults, individuals between 3 and 7 months for the first clutch individuals and from 3 to 5.5 months for the second clutch individuals; Adults I, individuals reaching sexual maturity from 7 to 12 months for the firstclutch individuals and from 5.5 to 12 months for the second clutch individuals; Adults II, individuals older than one year.

TABLE 1

Average growing effort (mm day ${ }^{-1}$.10), by season and age class for the first clutch captured S. scalaris individuals.

\begin{tabular}{|c|c|c|c|c|c|}
\hline $\begin{array}{l}\text { Season } \\
\text { Age class }\end{array}$ & 1 & 2 & 3. & 4 & Average \\
\hline Juvenile & - & - & 0.050 & & 0.050 \\
\hline $\begin{array}{l}\text { Subad ult } \\
\text { male }\end{array}$ & - & - & - & 0.020 & 0.020 \\
\hline $\begin{array}{l}\text { Subad ult } \\
\text { female }\end{array}$ & - & - & - & 0.019 & 0.019 \\
\hline $\begin{array}{c}\text { Adult male } \\
1\end{array}$ & 0.013 & 0.009 & 0.010 & 0.009 & 0.010 \\
\hline $\begin{array}{c}\text { Adult female } \\
\text { I }\end{array}$ & 0.014 & 0.013 & 0.009 & 0.010 & 0.012 \\
\hline $\begin{array}{c}\text { Adult male } \\
11\end{array}$ & 0.003 & 0.005 & 0.004 & 0.003 & 0.004 \\
\hline $\begin{array}{c}\text { Adult female } \\
\text { II }\end{array}$ & 0.004 & 0.006 & 0.005 & 0.003 & 0.005 \\
\hline
\end{tabular}


As we can observe in Tables 1 and 2, GE drastically diminishes as the organisms grow. The maximum GE is showed by the juveniles during the autumn. Males and females exhibit practically equal GE in all age classes considered. In the case of the adults, where it is possible to compare among seasons, we see a slight quicker growth during spring.
Thereexists good fit both with the semilog and linear plots, for both clutches individuals. Testing statistically the correlation coefficients found in each plot (with Student's t-test and $\mathrm{f}$ test), we found the best fit is for the plot number $1 \mathrm{~d}$ ) for the first clutch individuals, where $y=0.3205 \mathrm{X}$ $0.0049 ; r=0.81$; and the plot number $2 \mathrm{~d}$ ) for those of the second clutch, where $y=0.2426 x$ $0.0028 ; r=0.65$.

TABLE 2

Average growing effort (mm.day-1.10), by season and age class for the second clutch captured S. scalaris individuals.

\begin{tabular}{|c|c|c|c|c|c|}
\hline \multirow{2}{*}{\multicolumn{6}{|c|}{$\begin{array}{c}\text { Season } \\
\text { Age class }\end{array}$}} \\
\hline & & & & & \\
\hline Juvenile & - & - & 0.090 & - & 0.090 \\
\hline $\begin{array}{l}\text { Subadult } \\
\text { Male }\end{array}$ & - & - & - & 0.029 & 0.029 \\
\hline $\begin{array}{l}\text { Subadult } \\
\text { Female }\end{array}$ & - & - & - & 0.030 & 0.030 \\
\hline$\underset{1}{\text { Adult male }}$ & 0.014 & 0.011 & 0.009 & 0.010 & 0.011 \\
\hline $\begin{array}{l}\text { Adult female } \\
\text { I }\end{array}$ & 0.017 & 0.010 & 0.010 & 0.009 & 0.012 \\
\hline $\begin{array}{c}\text { Adult male } \\
\text { II }\end{array}$ & 0.004 & 0.003 & 0.004 & 0.005 & 0.004 \\
\hline $\begin{array}{c}\text { Adult female } \\
\text { II }\end{array}$ & 0.003 & 0.005 & 0.006 & 0.004 & 0.005 \\
\hline
\end{tabular}

Figs. 1 and 2 show the calculated pair values for the RGR and the geometric mean of the individual body size for each individual recaptured, plotted in semilog, log, and linear paper. 

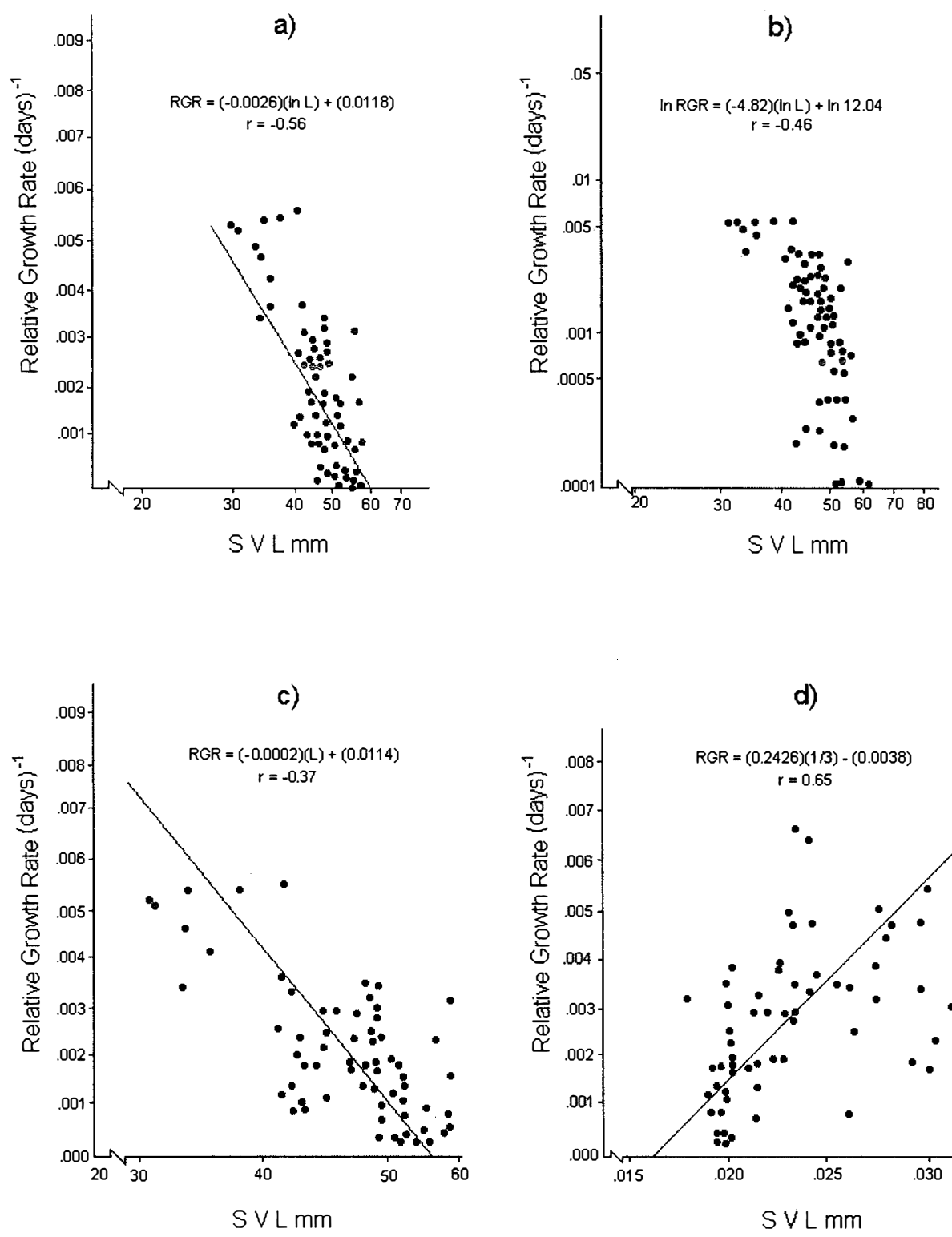

d)

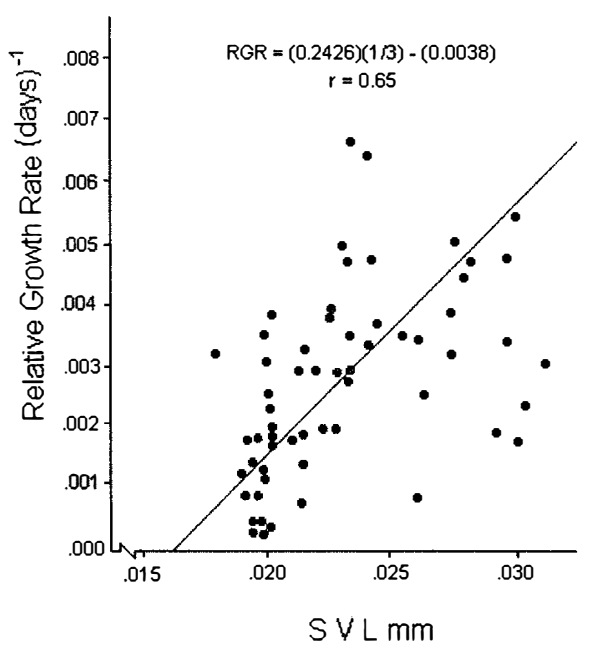

Fig. 1. Sceloporus scalaris first clutch growth data adjusted to: a). A Gompertz curve. b). A Power curve. c). A logistic curve. d). A Bertalanffy curve. 

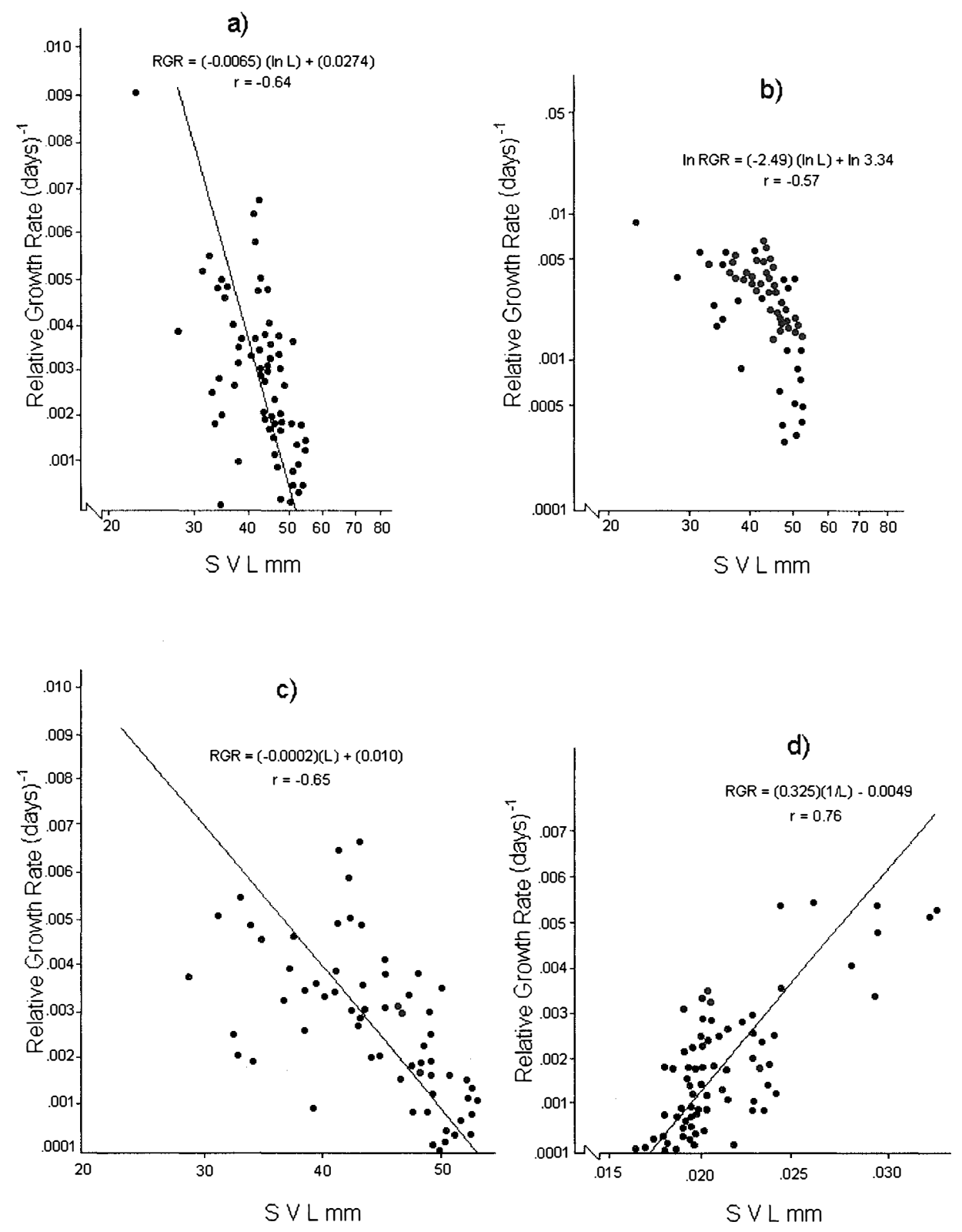

Fig. 2. Sceloporus scalaris second clutch growth data adjusted to: a). A Gompertz curve. b). A Power curve. c). A Logistic curve. d). A Bertal anffy curve. 
The growth curve that fits the $S$. scalaris growth data best is the Bertalanffy curve. The integrated equation of this curve is:

$$
S=S_{0}\left[1-\operatorname{Exp}^{-1}\left(t+T_{0}\right)\right]
$$

Where:

$$
\begin{aligned}
& \mathrm{S}=\text { Size } \\
& \mathrm{t}=\text { Time } \\
& \mathrm{S}_{0}=\text { Asymptotic size } \\
& \mathrm{b}=\text { Intrinsic growth rate } \\
& \mathrm{t}_{0}=\text { Initial time }
\end{aligned}
$$

The Bertalanffy model is based on the hypothesis that the growth represents the difference between synthetic (anabolic) processes and degradation (catabolic) processes and the synthetic processes are directly proportional to the body mass (Bertalanffy 1957, Fabens 1965). Although it is more accurate to use the integrated equation, it is easier touse the differential equation, which establishes the relationship between the Relative Growth Rate and the size (Kaufmann 1981):

$$
R G R=a \frac{\text { I }}{S}-b
$$

Where: $a$ is the axis intercept and $b$ is the slope of the line (Figs. Id and 2d).

The Bertalanffy linear growth model is the most common found for reptiles (Trivers 1976, Turner and Gist 1970, Schoener and Schoener 1978, Van Devender 1978). Previously, it had been reported that for small and short-lived lizards like S. scalaris, the best model fitted is the logistic one (Andrews 1982, Dunham 1978, Tinkle 1967). The growth patterns of bigger reptiles of longer life follow the Bertalanffy model (Chebreck and Joanen 1979, Webb et al.1978, Wilbur 1975).
The growth pattern of S. scalaris, atLa Michilİa follows the predictions proposed by the Bertalanffy model, i.e., maximum growth rates are reached in the younger age classes and these rates decrease as the size increases.

The second data source, independent of the mark-recapture data analyzed, was the measure of the monthly size of individuals of the same cohort during one year. This could be only achieved because $S$. scalaris, newborn appear in two short well-defined period: 15 days during September for the first clutch individuals and 15 days during October for the second clutch.

The measured growth rates by day and by month, for 1981, are showed in Table 3. Growth rates are relatively high from October to March for both clutch individuals. The maximum growth for first clutch individuals occurs from October to December.During January to Marchexhibit lower growth values than second clutch individuals, whichreach their higher values during this period. From May to September the growth rates fall drastically, for both clutch size individuals, and show littlechange up to the age of 1 year (the next October).

Integrating the data by the mark-recapture methods and by the cohort-record method, it was possible to build the body evolution curves for both males and females (Fig. 3). Juvenile males grow quickly from September to April and relatively slowly from May. Juvenile females show, from September to April, a lower growth rate than juvenile males, but from May they do not exhibit an abrupt decline in rate as do the males. Thus, at the age of 13 months and with a size of $51 \mathrm{~mm}$ the females reaches the average size of the males. From the second April (month 17) females not only are bigger, but grow more quickly than males. 
TABLE 3

Growing rate (mm/day) for S.scalaris individuals for the 1981 year.

\begin{tabular}{|c|c|c|c|c|c|}
\hline \multicolumn{2}{|l|}{ Age (months) } & \multicolumn{3}{|c|}{ Age (months) } & \multirow{2}{*}{ Females } \\
\hline First clutch & Males & Females & Second clutch & Males & \\
\hline 1 & 0.07 & 0.07 & - & - & - \\
\hline 2 & 0.27 & 0.13 & 1 & 0.17 & 0.17 \\
\hline 3 & 0.22 & 0.23 & 2 & 0.17 & 0.17 \\
\hline 4 & 0.17 & 0.10 & 3 & 0.17 & 0.10 \\
\hline 5 & 0.10 & 0.13 & 4 & 0.17 & 0.17 \\
\hline 6 & 0.13 & 0.10 & 5 & 0.15 & 0.20 \\
\hline 7 & 0.10 & 0.10 & 6 & 0.17 & 0.20 \\
\hline 8 & 0.07 & 0.08 & 7 & 0.07 & 0.13 \\
\hline 9 & 0.06 & 0.07 & 8 & 0.07 & 0.08 \\
\hline 10 & 0.02 & 0.05 & 9 & 0.02 & 0.03 \\
\hline 11 & 0.02 & 0.03 & 10 & 0.02 & 0.03 \\
\hline 12 & 0.01 & 0.02 & 11 & 0.01 & 0.02 \\
\hline- & - & - & 12 & 0.01 & 0.02 \\
\hline
\end{tabular}

Periods: $1=$ Sep to Oct; $2=$ Oct to Nov; $3=$ Nov to Dec; $4=$ Dec to Jan; $5=$ Jan to Feb; 6=Feb to Mar; 7= Mar to Apr; 8=Apr to May; $9=$ May to Jun; $10=$ Jun to Jul; $11=$ Jul to Aug, and 12= Aug to Sep.

The second clutch individuals follows basically the same pattern, but their growth rate is slightly faster, for both males and females, which is even more easily observed from the second January (month 16) to their second May (month 20). At the age of 20 months and with a size of $55 \mathrm{~mm}$ the second clutch individuals reaches in size to the first clutch individuals and it is not possible posteriorly to differentiate among them only by their size.

\section{DISCUSSION}

There are many interdependent factors that determine the growthrate of any animal: available nourishment and water, phenological phase of theindividual, inter-and intraspecific competition, predation, social environment, and for lizards, even tail breakage.

Individual growth varies with the available energy, thus many lizard species exhibit quicker growth rates during the season of higher prey availability (Dunham 1978, Medica et al. 1975) or when they have access to supplementary food (Licht 1974). However, the direct relationship between nourishment and growth rate could be masked by the effect on the growth rates produced by water availability (Nagy 1973, Smith 1977) or by the existence of circadian rhythms of appetite and other endogenous factors (Jackson 1970, Licht 1972).

At the La Michilİa Biosphere Reserve, the maximum prey-availability period for $S$. scalaris is from June to October. During these months the abundance and biomass of their prey reaches their peak (Ortega and Hern ndez 1983). Because of this, we mustexpect the maximumgrowth rate for $S$. scalaris individuals to be from June to October, which does not occur.

From June to September there are only adult individuals of this species in the zone (Ortega 1986). Juvenile individuals reaches their highest numbers from October to January, and the subadults from January toMarch. For this reason, in spite that maximum nourishment availability is foundduring the summermonths, the faster growth rates are found from October to March. The younger age classes shows the quickest growth rates in spite than they growth only during the last optimum month of the year (October). 


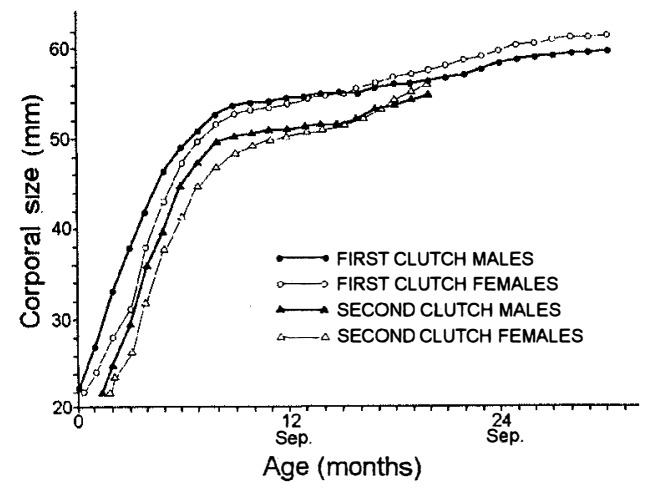

Fig. 3. Body evolution of S. scalaris males and females

The reproductive period of $S$. scalaris is correlated with the seasonality ofthe environment at La Michilİa Biosphere Reserve. Adult $S$. scalaris oviparous females exhibit two periods carrying oviducal eggs, June and August (Ortega 1986). Reproductive activities occurs just when thenourishmentavailabilityis the most propitious for use this energy for reproductive purposes (Ortega 1983). Besides, S. scalaris eggs are laying during the rainy season, it is to say during the optimum humidity conditions to conclude the embrionary development (Ortega 1986). The new born $S$. scalaris individuals appears during the last month of the optimum period of the year and growth at the fastest rates.

Such adaptations to the environment determine many key population attributes of this species in this zone (Ortega 1986). The sexual maturity age of S. scalaris is very early at La Michilİa, only 4.5 to 6 months (Ortega 1986). Undoubtedly, the growth pattern of $S$. scalaris at La Michilìa Biosphere Reserve can help explain the structure and dynamics of this population.

\section{ACKNOWLEDGMENTS}

This work was supported jointly by the Consejo Nacional de Ciencia y Tecnología (CONACyT), the Instituto de Ecología, and The Centro de Investigaciones Biológicas del Noroeste, of México; by the Ecole Normale Superieure, the Counceil National de la Recherche Scientifique (CNRS) of France and by the MAB UNESCO program. We thank J. Monge-Nájera and two anonymous reviewers for theirhelpfulsuggestions on an earlier version of this manuscript, Ellis Glazier for editing of the English language text and Lolita Vázquez for typing the manuscript.

\section{RESUMEN}

Usando métodos de Marca-Recaptura estudiamos el esfuerzo de crecimiento de Sceloporus scalaris en la Reserva de la Biosfera de La Michilía, Durango, México. Seanalizaron 146 registros de recaptura sobre 68 individuos en cuatro años de estudio en un transecto de $50000 \mathrm{~m}^{2}$. El esfuerzo de crecimiento disminuye drasticamente conforme el individuo crece, es casi igual para los machos y hembras de las dos puestas, y en el caso de los adultos se registró un crecimiento más rapido en primavera. El patrón de crecimiento sigue las predicciones propuestas por el modelo de Bertalanffy. Los recién nacidos de $S$. scalaris eclosionan cuando la disponibilidad de alimento es todavía la más propicia. La madurez sexual de los individuos es muy precoz en $\mathrm{La}$ Michilía: de 4.5 a 6 meses. El patrón de crecimiento de $S$. scalaris en La Michilía ayuda a explicar la estructura y dinámica de esta población. 


\section{REFERENCES}

Anderson, D.J. 1962. Egg laying and nesting in Sceloporus scalaris slevini. Herpetologica 18: 162-164.

Anderson, D.J. 1972. Pattern polymorphism in the bunchgrass lizard Sceloporus scalaris slevini. J. Herpetol. 6: 80.

Andrews, R.M. 1976. Growth rate in island lizards. Copeia 1976: $477-482$

Andrews, R.M. 1982. Patterns of growth in reptiles, p. 273319. In C. Gans \& F. Pough (eds.). Biology of Reptilia. Academic, New York. Vol. 13.

Ballinger, E.R. \& J.D. Congdon. 1981. Population ecology and life history of a montane lizard (Sceloporus scalaris) in southeastern Arizona. J. Nat. Hist.. 15: 213-222.

Barbault, R. 1973. Structure et dinamique d' un peuplement de lezards: les Scincides de la savane de Lamto (Cote D'Ivoire). These de Doctorate Sciences, Univ. Paris VI.

Barbault, R. 1974. Structure et dynamique d'un peuplement de lezards: les Scincides de la savane de Lamto (Cote D'Ivoire). Terre Vie 28: 352-428.

Barbault, R. 1975: Dynamique des populations de lezards. Bull. Soc. Zool. France 99: 345-361.

Barbault, R. 1981 .Ecologie des population etdes peuplements Masson, Paris. 220 p.

Bertalanffy, L. Von. 1957. Quantitative laws in metabolism and growth. Q. Rev. Biol. 32: 217-231

Bertalanffy, L. Von. 1960. Principles and theory of growth, p. 137-259. In W.W. Nowinsky (ed.). Fundamental aspects of norman and malignant growth. Elsevier, Amsterdam.

Chabrek, R.H. \& T. Joanen. 1979. Growth rates of American Alligators in Lousiana. Herpetologica 35: 51-57.

Dunham, A. E. 1978. Food availability as proximate factor infuencing individual growth rates in the iguanid lizard Sceloporus merriami. Ecology. 59: 770-778.

Fabens, A.J. 1965. Properties and fitting ofthe Von Bertalanffy growth curve. Growth 29: 265-289.

Greene, H.W. 1970. Mode de reproduction in lizard and snakes of the GÛmez FarÌas region, Tamaulipas MÈxico. Copeia 1970: 565-568.

Jackson, C. G. Jr. 1970. A biometrical study of growth in Pseudemys concinna suwanniensis. Copeia 1970: 528534
Kaufmann, K.W. 1981. Fitting and using growth curves. Oecologia (Berl.) 49: 293-299.

Licht, P. 1972. Problems in experimentation on timing mechanism for annual pysiological cycles in reptiles, $p$. 681-711. In F. E. South, J. P. Hannon, J. R. Willis, E. T. Pengelley, \& N. R. Albert (eds.). Hibernation and hypotermia, perspectives and challenges. Elsevier, Amsterdam.

Licht, P. 1974. Response of Anolis lizards to food supplementation in nature. Copeia 1974: 215-221.

MartÌnez,E. \& M. Saldivar. 1978. Unidades de vegetaciÛn en la Reserva de la BiÛsfera de La Michill̀a en el Estado de Durango. Publicaciûn No. 4. Instituto de Ecologİa. MÈxico, Distrito Federal. 198 p.

Medica, P. A., R. B. Bury, \& F. B. Turner. 1975. Growth of desert tortoise (Gopherus agassizi) in Nevada. Copeia 1975: 639-643.

Nagy, K. A. 1973. Behavior, diet and reproduction in a desert lizard, Sauromalus obesus. Copeia 1973: 93-102.

Newlin, M.E. 1976. Reproduction in the Bunch grass lizard Sceloporus scalaris. Herpetologica 32: 171-184.

Ortega, A. \& L. Hernández. 1983. Abundancia relativa de insectos en un medio estacional: su influencia en la historia de vida de dos iguánidos simpátricos. Folia entomológica 55: 129-144.

Ortega, A. 1986. Din -mica y estrategias demográficas de dos poblaciones de iguanidos simpatricos en la reserva de la biosfera la Michilia. Tesis Doctoral. Instituto Politécnico Nacional. México, Distrito Federal. 329 p.

Schoener, T. W., \& A. Schoener. 1978. Estimating and interpreting body-size growth in some Anolis lizards. Copeia 1978: 390-405.

Smith, D.C. 1977. Interspecific competition and the demography of two lizards. Ph. D. Thesis, University of Michigan. Ann Arbor, Michigan. 192 p.

Smith, H. M. 1939. The Mexican and Central American lizards of the genus Sceloporus. Field Mus. Nat. Hist., Zool. Ser. 26: 1-397.

Smith, H. M. \& W. P. Hall. 1974. Contribution to the concepts of reproductive cycles and the systematics of the scalaris group of the lizard genus Sceloporus. Gt. Basin Nat. 34: 97-104.

Smith, H.M. \& I. Poglayen. 1958. Noteworthy herptiles from MÈxico. Herpetologica 14: 11-15. 
Sokal, B. R. \& F. J. Rohlf. 1969. Biometry. Freeman, San Francisco. 599 p.

Stebbins, R.C. 1954. Amhibians and reptiles of western North America. Mcgraw-Hill. New York. 528 p.

Stebbins, R.C. 1966. A field guide to western reptiles and amphibians. Houghton Mifflin. Boston. 270 p.

Thomas, A.R. \& J. R. Dixon. 1976. A re-evaluation of the Sceloporus scalaris group (Sauria: Iguanidae). Southwestern Nat. 20: 523-525.

Tinkle, D. W. 1967. The life and demography of the sideblotched lizard. Misc. Publ. Mus. Zool. Univ. Michigan. 132: 1-182.

Trivers, R.L. 1976. Sexual selection and resource-accruing abilities in Anolis germani. Evolution 30: 253-269.

Turner, F. B. \& C. S. Gist. 1970. Observations of lizards and tree frogs in an irradiated Puerto Rican Forest, p. E25-
E49. In H. T. Odum \& R. F. Pigeon (eds.). A tropical rain forest. US Atomic Energy Comm. Springfield, Virginia.

Van Devender, W. R. 1978. Growth ecology of a tropical lizard, Basiliscus basiliscus basiliscus. Ecology 59: 10311038.

Van Devender, W.R. \& C.H. Lowe Jr. 1977. Amphibians and reptiles of YepÛmera, Chihuahua, MÈxico. J. Herpetol. 11: $51-50$.

Webb, G.J.W., H. Messel, J. Crawford, \& M. J. Yerbury. 1978. Growth rates of Crocodylus porosus from Arnhem Land, Northern Australia. Austral. Wild. Res. 5:385-399.

White, M.J.D. 1978. Modes of speciation. W.H. Freeman. San Francisco. 284 p.

Wilbur, H. M. 1975. A growth model for the turtle Clrrysemys picta. Copeia 1975: 337-343. 